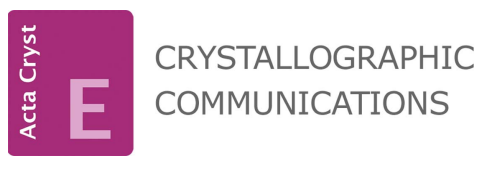

ISSN 2056-9890

Received 26 October 2020

Accepted 11 November 2020

Edited by M. Weil, Vienna University of Technology, Austria

Keywords: crystal structure; benzimidazoles; thiazoles; DFT analysis; reactivity.

CCDC reference: 2043709

Supporting information: this article has supporting information at journals.iucr.org/e

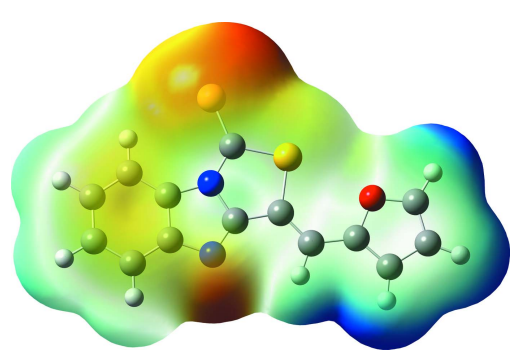

OPEN $\odot$ ACCESS

\section{Molecular and crystal structure, Hirshfeld analysis and DFT investigation of 5-(furan-2-ylmethyl- idene)thiazolo[3,4-a]benzimidazole-2-thione}

\author{
Hafsa Khaldi, ${ }^{a}$ Ahmed Djafri, ${ }^{\text {b,c }}$ Youcef Megrouss, ${ }^{c}$ Nawel Khelloul, ${ }^{c}$ Abdelkader \\ Chouaih $^{\mathrm{c} *}$ and Ayada Djafri ${ }^{\mathrm{a}}$
}

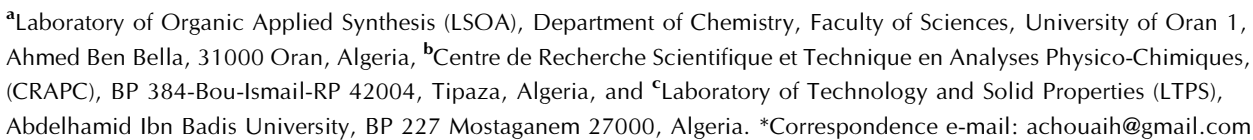

The thiazolo[3,4-a]benzimidazole fused-ring system in the title compound, $\mathrm{C}_{14} \mathrm{H}_{8} \mathrm{~N}_{2} \mathrm{OS}_{2}$, is nearly planar, the r.m.s. deviation being $0.0073 \AA$. The thiazolobenzimidazole-2-thione system is almost in the same plane as the furan-2-ylmethylene moiety, with a dihedral angle of $5.6(2)^{\circ}$ between the two leastsquares planes. In the crystal, adjacent molecules are connected by weak intermolecular interactions $(\mathrm{C}-\mathrm{H} \cdots \mathrm{N}$ and slipped $\pi-\pi$ stacking $)$ into a threedimensional network. The nature of the intermolecular interactions was also quantified by Hirshfeld surface analysis. DFT analysis indicates a good agreement of the experimentally determined and the theoretically calculated molecular structures.

\section{Chemical context}

The synthesis and biological activity of thiazolobenzimidazoles were first studied several decades ago (Ogura et al., 1968; Krasovskii \& Kochergin, 1972; Alper \& Taurins, 1967). With regard to their biological activity, thiazolobenzimidazole derivatives have been evaluated in particular for their inhibitory effects on HIV-1 (Chimirri et al., 1999; Roth et al., 1997) and their use as antibacterial (Oh et al., 1995), anti-inflammatory (Bender et al., 1985), antidiabetic (El-Shorbagi et al., 2001), broncholytic (Park et al., 1993), antiprotozoal (Singh, 1970), anticonvulsant (Sharpe et al., 1971) and antidepressant (Miller \& Bambury, 1972) agents. Some thiazolobenzimidazole derivatives are also used for the treatment of cancer and bone diseases (Al-Rashood \& Abdel-Aziz, 2010). Furthermore, compounds with the benzimidazole moiety have been developed into useful materials for usage in non-linear optical fields (Vijayan et al., 2004) or photovoltaic cells (Bodedla et al., 2016; Gong et al., 2010).

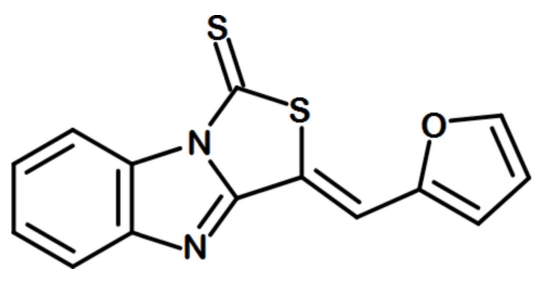

We report in this communication the synthesis, molecular and crystal structures and Hirshfeld surface analysis of the title thiazolo derivative. In addition, the HOMO-LUMO 
energies, molecular electrostatic potential and chemical reactivity descriptors are described on the basis of theoretical calculations.

\section{Structural commentary}

The molecular structure of the title compound is shown in Fig. 1. The tricyclic thiazolobenzimidazole group, consisting of a benzimidazole unit fused to a thiazole ring, is bonded to a furan-2-yl-methylene moiety at carbon atom C6. As expected, the thiazolo[3,4-a]benzimidazole group is planar with an r.m.s. deviation of $0.0073 \AA$ for the thirteen (C6-C14/N1/N2/S1/S2) non $\mathrm{H}$-atoms. The furan-2-yl-methylene moiety is also planar, with an r.m.s deviation of $0.0028 \AA$ for the six (C1-C5/O1) non $\mathrm{H}$-atoms. The two ring systems are almost in the same plane, their least-squares planes subtending a dihedral angle of $5.6(2)^{\circ}$. The molecule exists in a $Z$ configuration with respect to the $\mathrm{C} 5=\mathrm{C} 6$ bond. The $\mathrm{S} 1-\mathrm{C} 8$ and $\mathrm{S} 1-\mathrm{C} 6$ distances, 1.739 (4) and 1.775 (3) $\AA$, respectively, are in agreement with a $\mathrm{C}-\mathrm{S}$ single bond of a thiazole ring (Rahmani et al., 2016). In comparison, the $\mathrm{S} 2-\mathrm{C} 8$ bond [1.612 (4) $\AA$ ] of the thione moiety is much shorter as a result of its double-bond character and the presence of a delocalized $\pi$-electronic system throughout the entire thiazolobenzimidazole ring system (Liang et al., 2009). The bond lengths of the thiazolobenzimidazole and furan rings are similar than those in a series of thiazolo[3,2-a]benzimidazole and thiazolo[3,4-a]benzimidazole compounds (Bruno et al., 1996; Wang et al., 2011). The intramolecular $\mathrm{C} 10-\mathrm{H} 10 \cdots \mathrm{S} 2$ hydrogen-bonding interaction (Table 1) helps to stabilize the molecular conformation.

\section{Supramolecular features and Hirshfeld surface analysis}

In similar reported structures containing thiazole ring systems, the crystal packing is mainly based on short contacts and weak $\pi-\pi$ interactions (Djafri et al., 2017). In the crystal packing of the title compound, weak $\mathrm{C} 3-\mathrm{H} 3$ aromatic $\cdot \mathrm{N} 2{ }^{\mathrm{i}}$ hydrogen bonds (Table 1) connect the molecules into dimers (Fig. 2).

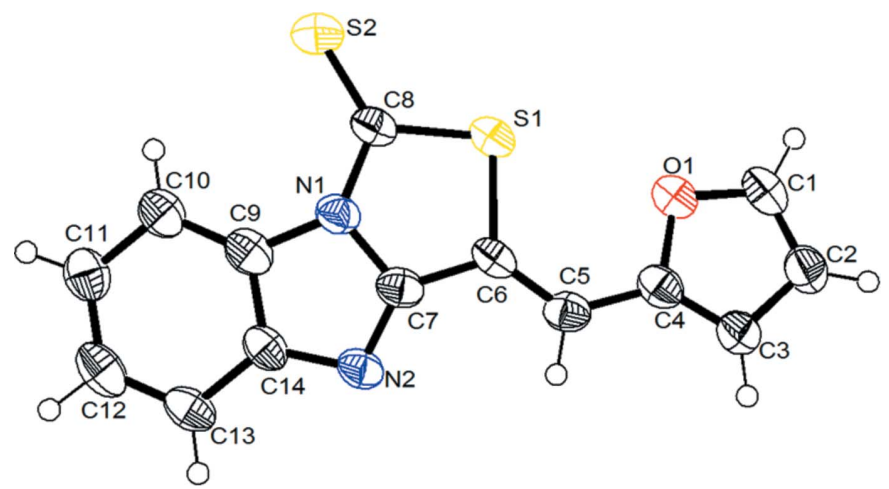

Figure 1

The molecular structure of the title compound showing the atomnumbering scheme. Displacement ellipsoids are drawn at the $50 \%$ probability level.
Table 1

Hydrogen-bond geometry $\left(\AA,^{\circ}\right)$.

\begin{tabular}{lllll}
\hline$D-\mathrm{H} \cdots A$ & $D-\mathrm{H}$ & $\mathrm{H} \cdots A$ & $D \cdots A$ & $D-\mathrm{H} \cdots A$ \\
\hline $\mathrm{C} 10-\mathrm{H} 10 \cdots \mathrm{S} 2$ & 0.93 & 2.94 & $3.476(4)$ & 119 \\
$\mathrm{C} 3-\mathrm{H} 3 \cdots \mathrm{N} 2^{\mathrm{i}}$ & 0.93 & 2.62 & $3.474(5)$ & 154 \\
$\mathrm{C} 1-\mathrm{H} 1 \cdots 2^{\mathrm{ii}}$ & 0.93 & 2.89 & $3.788(4)$ & 163
\end{tabular}

Symmetry codes: (i) $-x+\frac{1}{2}, y+\frac{1}{2},-z+\frac{3}{2}$; (ii) $-x,-y+1,-z+2$.

Additional $\pi-\pi$ stacking interactions between adjacent thiazolobenzimidazole ring systems link the dimers into a threedimensional network structure, with centroid-to-centroid distances of 3.6523 (18) ^ (slippage $1.141 \AA$ ) and 3.6515 (1) (slippage $1.137 \AA$ ) between the thiazole ring and the benzene ring of one thiazolobenzimidazole ring system, and between the imidazole ring and the benzene ring of another thiazolobenzimidazole ring system, respectively.

Hirshfeld surface (HS) analysis of the title compound was performed using Crystal Explorer 17 (Turner et al., 2017) with the surface mapped over $d_{\text {norm }}$ as described in the literature (Yahiaoui et al., 2019). In the $d_{\text {norm }}$ surface, strong intermolecular interactions appear as red spots (Bahoussi et al., 2017; Khelloul et al., 2016) as depicted in Fig. $3 a$ (here originating particularly from the $\mathrm{C}-\mathrm{H} \cdots \mathrm{N}$ hydrogen bond). The presence of $\pi-\pi$ stacking interactions is indicated by red and blue triangles on the shape-index surface as can be seen in Fig. $3 b$. In Fig. $3 c$, the other red spots indicate also the presence of a weaker $\mathrm{C}-\mathrm{H} \cdots \mathrm{S}$ hydrogen bond (between $\mathrm{H} 3$ and $\mathrm{S} 2$ ) and $\mathrm{C}-\mathrm{H} \cdots \mathrm{N}$ (between $\mathrm{H} 1$ and $\mathrm{N} 2$ ). The overall two-dimensional fingerprint (FP) plots, and those delineated into $\mathrm{H} \cdots \mathrm{H}, \mathrm{C} \cdots \mathrm{H} / \mathrm{H} \cdots \mathrm{C}, \mathrm{S} \cdots \mathrm{H} / \mathrm{H} \cdots \mathrm{S}, \mathrm{N} \cdots \mathrm{H} / \mathrm{H} \cdots \mathrm{N}$ and

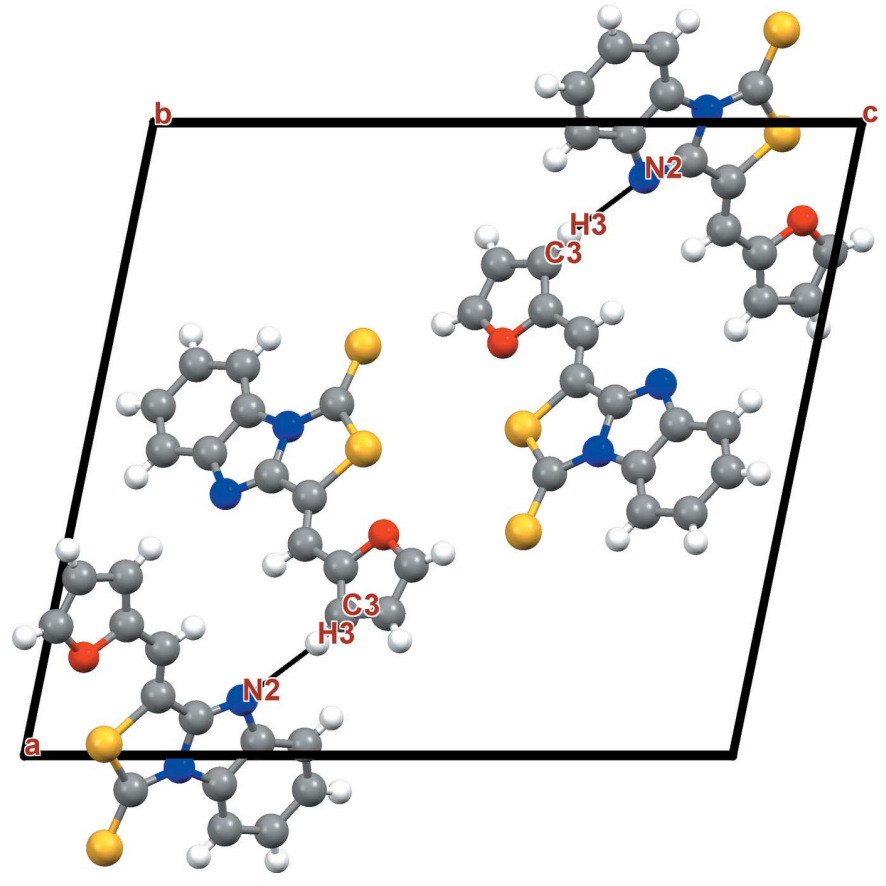

Figure 2

Crystal packing diagram of the title compound with hydrogen bonds (dashed lines) viewed along the $b$ axis. 

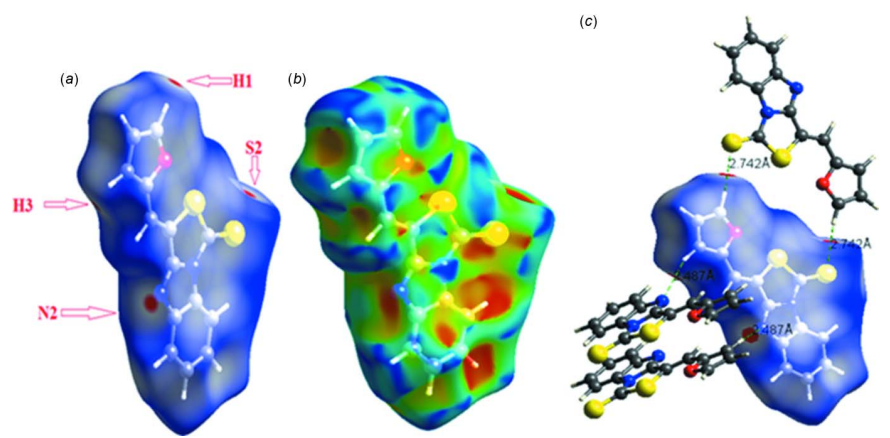

Figure 3

Hirshfeld surfaces for visualizing the intermolecular contacts of the title compound: (a) $d_{\text {norm }}$ Hirshfeld surface, $(b)$ shape-index and $(c) d_{\text {norm }}$ highlighting the regions of the $\mathrm{C}-\mathrm{H} \cdots \mathrm{S}$ and $\mathrm{C}-\mathrm{H} \cdots \mathrm{N}$ hydrogen bonds.

C...C contacts are shown in Fig. 4. H. . H contacts are the dominant interactions with a contribution of $29.8 \%$ to the overall HS. The S $\cdots \mathrm{H} / \mathrm{H} \cdots \mathrm{S}$ interactions appear as the next largest region of the FP plot, highly concentrated at the edges, characteristic of hydrogen-bond interactions with an overall HS contribution of $19.6 \%$. The $\mathrm{C} \cdots \mathrm{H} / \mathrm{H} \cdots \mathrm{C}$ interactions are illustrated by two symmetrical wings on the left and right sides (16.5\% contribution). The C..C contacts, which are the measure of $\pi-\pi$ stacking interactions, occupy $9.1 \%$ of the HS and appear as a unique triangle. The $\mathrm{N} \cdots \mathrm{H} / \mathrm{H} \cdots \mathrm{N}$ contacts are represented by a pair of sharp spikes and make a contribution of $6.6 \%$. Other intermolecular contacts in the HS mapping contribution less than $5 \%$.

\section{Theoretical calculations}

The hybrid functional B3LYP (Becke's three-parameter hybrid model using the Lee-Yang Parr correlation functional) with the 6-311G (d, p) basis set (Becke, 1993) were used in all calculations as implemented in Gaussian 09 (Frisch et al., 2009). Theoretical calculations were performed to obtain the optimized molecular structure of the title compound in the gas
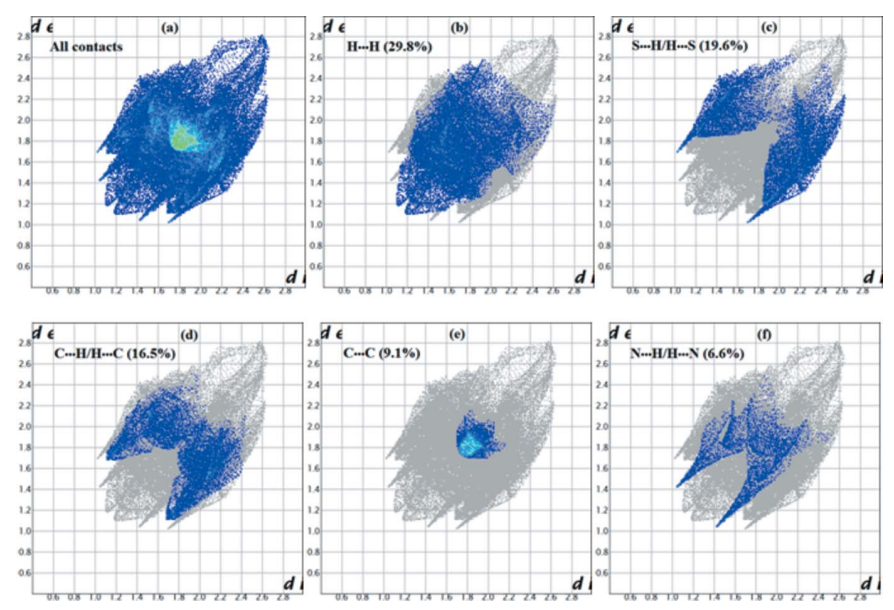

Figure 4

Two-dimensional fingerprint plots showing the contributions of different types of interactions: $(a)$ all intermolecular contacts, $(b) \mathrm{H} \cdots \mathrm{H}$ contacts, (c) $\mathrm{S} \cdots \mathrm{H} / \mathrm{H} \cdots \mathrm{S}$ contacts, $(d) \mathrm{C} \cdots \mathrm{H} / \mathrm{H} \cdots \mathrm{C}$ contacts, $(e) \mathrm{C} \cdots \mathrm{C}$ contacts and $(f) \mathrm{N} \cdots \mathrm{H} / \mathrm{H} \cdots \mathrm{N}$ contacts. phase. The crystallographic information file was used as an input file in the GaussView 5 program (Frisch et al., 2000) to start structure optimization of the title compound. Comparison of the DFT-optimized molecular structure with the refined structure based on single crystal X-ray data revealed a good agreement (see supporting information for a detailed comparison of bond lengths and angles). Frontier molecular orbitals and the molecular electrostatic potential were calculated using the same level of theory.

\section{Frontier molecular orbital and chemical reactivity}

The frontier molecular orbitals, HOMO (highest occupied molecular orbital) and LUMO (lowest-unoccupied molecular orbital), are plotted to specify the distribution of electronic densities. The electron distribution of the HOMO-1, HOMO, LUMO and the LUMO+1 energy levels are shown in Fig. 5. As can be seen from the figure, the HOMO and LUMO are localized in the plane extending from the whole furan ring to the thiazolo-benzimidazole ring system. The frontier molecular orbital energies, EHOMO and ELUMO are -7.23 and $-1.87 \mathrm{eV}$, respectively, and the HOMO-LUMO gap is $5.36 \mathrm{eV}$. Since the gap energy is considered to be small, the molecule is defined as soft.

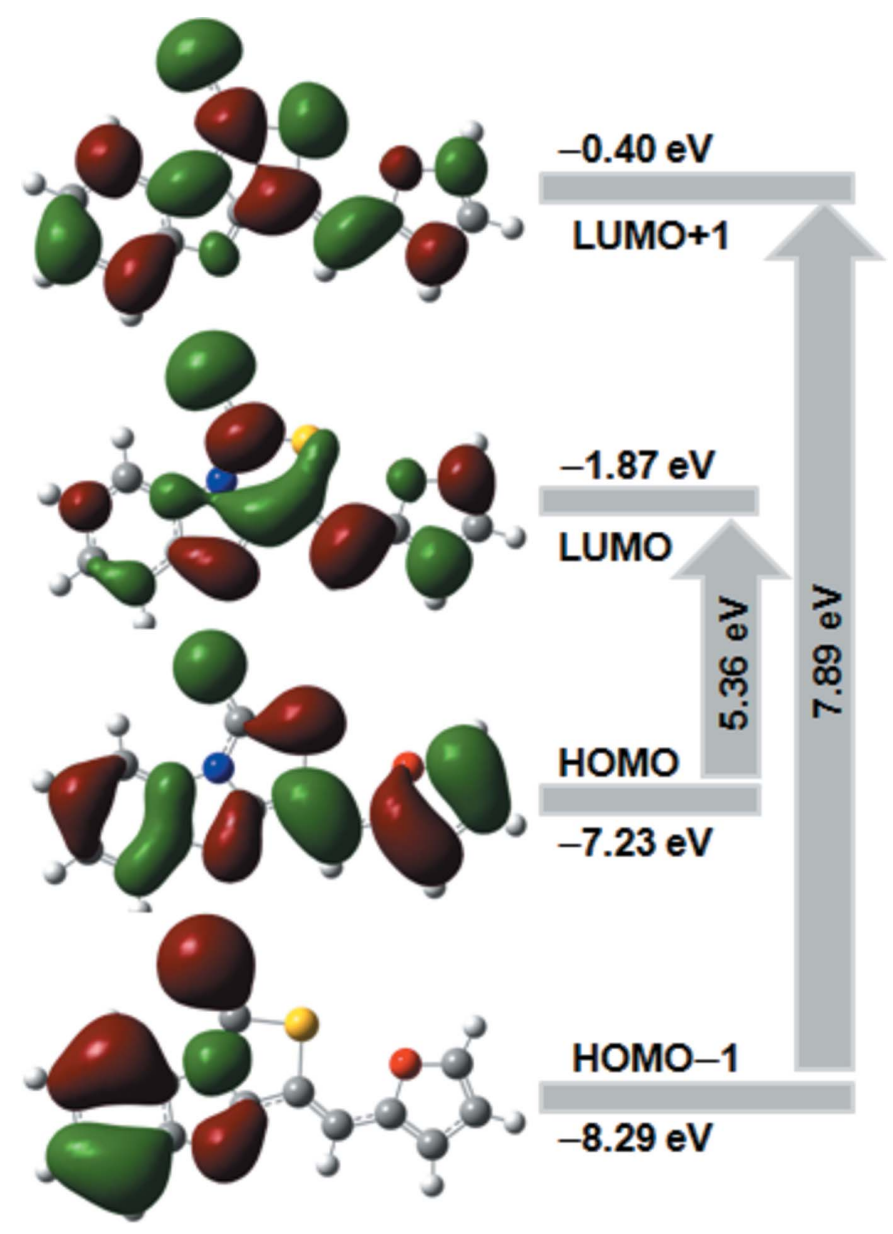

Figure 5

Molecular orbitals plot showing the frontier orbitals. 
Table 2

Frontier molecular orbital energies $(\mathrm{eV})$ and global chemical reactivity descriptors calculated using B3LYP/6-311G(d,p) level of theory.

\begin{tabular}{ll}
\hline Parameter & Calculated energy \\
\hline EHOMO & -7.23 \\
ELUMO & -1.87 \\
EHOMO-1 & -8.29 \\
ELUMO+1 & -0.40 \\
EHOMO-ELUMO (gap) & 5.36 \\
EHOMO-1 - ELUMO+1 (gap) & 7.89 \\
Ionization potential $(I)$ & 7.23 \\
Electron affinity $(A)$ & 1.87 \\
Chemical hardness $(\eta)$ & 2.68 \\
Chemical potential $(\mu)$ & -4.55 \\
Electronegativity $(\chi)$ & 4.55 \\
Electrophilicity $(\omega)$ & 3.86 \\
Hyper-hardness $(\Gamma)$ & 4.30 \\
\hline
\end{tabular}

Global chemical reactivity descriptor (GCRD) parameters can be obtained as reported in the literature (Belkafouf et al., 2019). The calculated values of the GCRD parameters for the title molecule are summarized in Table 2. The chemical stability of the title molecule is explained by the chemical potential $(\mu)$ value, which is $-4.55 \mathrm{eV}$. On the other hand, the chemical hardness $(\eta)$ value is $2.68 \mathrm{eV}$, indicating that the charge transfer occurs within the molecule. From Table 2, the electrophilic behaviour of the molecule is confirmed by the global electrophilicity $(\omega)$, which has a value of $3.86 \mathrm{eV}$. The structure-property relationship can be also described by the hyper-hardness descriptor $(\Gamma)$, which was introduced to investigate the reactivity or stability of molecules theoretically (Ghanavatkar et al., 2020). According to the results, the positive value of $\Gamma(+4.30 \mathrm{eV})$ indicates stability of the molecule.

\section{Molecular electrostatic potential analysis}

To predict reactive sites for electrophilic and nucleophilic attack, molecular electrostatic potential (MEP) surfaces were computed at the B3LYP/6-311G (d,p) level with the optimized structure using Gauss View (Frisch et al., 2000). The different values of the electrostatic potential at the MEP surface are

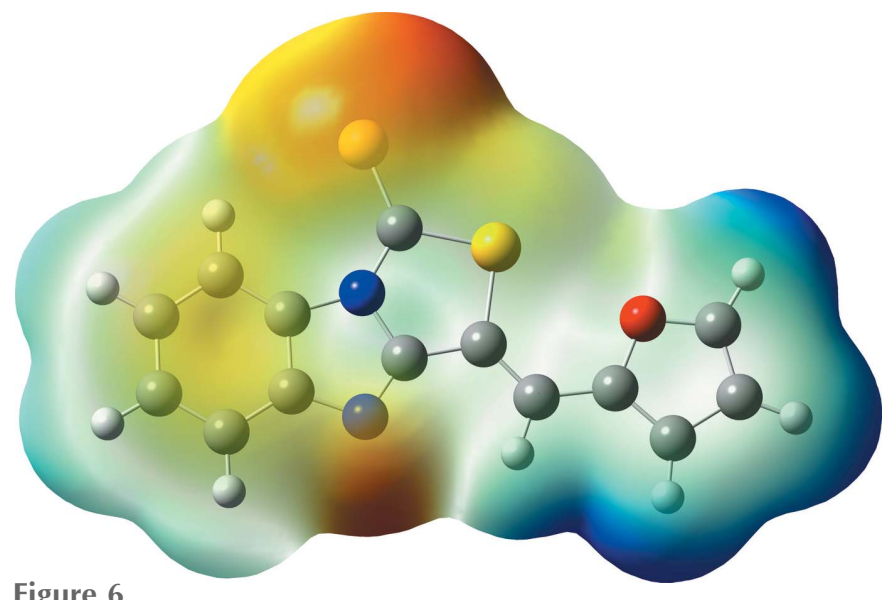

Figure 6

Molecular electrostatic potential map of the title molecule. represented by red, blue and green (Kourat et al., 2020). From Fig. 6, it is obvious that the negative potential regions (red) are associated with sulfur and nitrogen atoms whereas the positive potential regions (blue) are on the side of hydrogen atoms. It may also be seen in Fig. 6 that green areas cover parts of the molecule enveloping the $\pi$ system of the aromatic rings.

\section{Synthesis and spectral characterization}

The synthetic route preparation of the title compound is illustrated in Fig. 7. Initially, the tricyclic thiazolo(3,4a)benzimidazole (1) was obtained from amino phenylene dithiocarbamate and chloroacetic acid by the Hanztsch reaction. The title compound (3) was prepared by Knoevenagel condensation of furaldehyde $2(2 ; 0.01 \mathrm{~mol})$ and the tricyclic compound $(\mathbf{1} ; 0.02 \mathrm{~mol})$ in acetic acid $(10 \mathrm{ml})$ buffered by sodium acetate $(0.02 \mathrm{~mol})$. The reaction was monitored by TLC (petroleum ether/ethyl acetate, 8/2). After $4 \mathrm{~h}$ of refluxing and stirring, the brown solid obtained was filtered off, dried and recrystallized from ethanol to give the title compound, m.p. $493 \mathrm{~K}$, in a yield of $85 \%$.

Spectroscopic data (FT-IR, ${ }^{1} \mathrm{H}$ NMR and $\left.{ }^{13} \mathrm{C} \mathrm{NMR}\right)$ for (3). IR (KBr, cm $\left.{ }^{-1}\right)$ : 3099, 3076 and 3026 ( $\left.\mathrm{Csp}^{2}-\mathrm{H}_{\text {arom }}\right), 1602$ $(\mathrm{C}=\mathrm{N}), 1555-1464(\mathrm{C}=\mathrm{C}), 1390(\mathrm{C}=\mathrm{S}), 1324(-\mathrm{C}-\mathrm{S}-), 1259$ $(\mathrm{C}-\mathrm{N})$ and 815, $759\left(\mathrm{C}-\mathrm{H}_{\text {aryl }}\right) .{ }^{1} \mathrm{H} \mathrm{NMR}\left(300 \mathrm{MHz}, \mathrm{CDCl}_{3}, \delta\right.$ ppm) $J(\mathrm{~Hz}): 6,6\left(q, 1 \mathrm{H}, J_{3}=1.76 \mathrm{~Hz}\right.$, furan $), 6.80(d, 1 \mathrm{H}, J=$ $3.48 \mathrm{~Hz}$, furan $), 7.45\left(m, 2 \mathrm{H}, J_{3}=1.66 \mathrm{~Hz}, J_{4}=5,60\right.$ phenyl), $7.60(s, 1 \mathrm{H}, \mathrm{C}=\mathrm{CH}), 7.70(s, 1 \mathrm{H}$, furan $), 7.80\left(d, 1 \mathrm{H}, J_{3}=\right.$ $8.56 \mathrm{~Hz}$, phenyl), $8.50\left(d, 1 \mathrm{H}, J_{3}=8.72 \mathrm{~Hz}\right.$, phenyl). ${ }^{13} \mathrm{C} \mathrm{NMR}$ (75 MHz, $\left.\mathrm{CDCl}_{3}, \delta \mathrm{ppm}\right): 113.46,113.51,113.90,117.15$, 118.81, 120.65, 121.32, 125.59, 126.55, 131.00, 146.63, 149.48, $150.42(\mathrm{C}=\mathrm{N}), 187.15(\mathrm{C}=\mathrm{S})$.

\section{Refinement}

Crystal data, data collection and structure refinement details are summarized in Table 3. $\mathrm{H}$ atoms were placed in calculated positions $(\mathrm{C}-\mathrm{H}=0.93 \AA)$ and allowed to ride on their parent atoms with $U_{\text {iso }}(\mathrm{H})=1.2 U_{\text {eq }}(\mathrm{C})$.

\section{Funding information}

The authors gratefully acknowledge financial support via the PRFU project from the Algerian Ministry of Higher Education and Scientific Research, the Directorate General of Scientific Research and Technological Development (DGRSDT), Thematic Research Agency in Science and
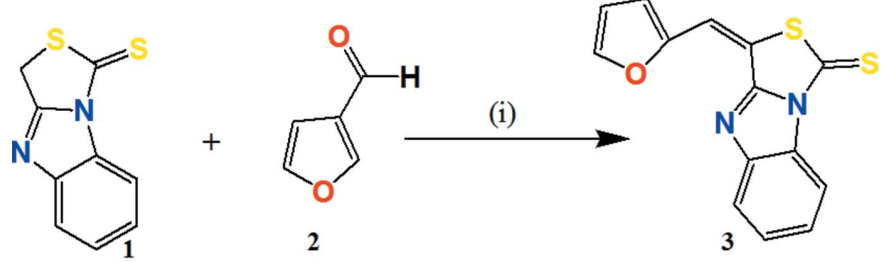

(i): Sodium acetate, Acetic acid, Reflux

Figure 7

Synthetic route for the title compound (3). 
Table 3

Experimental details.

\begin{tabular}{|c|c|}
\hline \multicolumn{2}{|l|}{ Crystal data } \\
\hline Chemical formula & $\mathrm{C}_{14} \mathrm{H}_{8} \mathrm{~N}_{2} \mathrm{OS}_{2}$ \\
\hline$M_{\mathrm{r}}$ & 284.34 \\
\hline Crystal system, space group & Monoclinic, $P 2_{1} / n$ \\
\hline Temperature $(\mathrm{K})$ & 295 \\
\hline$a, b, c(\AA)$ & $15.768(5), 4.7583(15), 17.316(6)$ \\
\hline$\beta\left({ }^{\circ}\right)$ & $101.572(8)$ \\
\hline$V\left(\AA^{3}\right)$ & $1272.8(7)$ \\
\hline$Z$ & 4 \\
\hline Radiation type & Mo $K \alpha$ \\
\hline$\mu\left(\mathrm{mm}^{-1}\right)$ & 0.41 \\
\hline Crystal size $(\mathrm{mm})$ & $0.58 \times 0.21 \times 0.20$ \\
\hline \multicolumn{2}{|l|}{ Data collection } \\
\hline Diffractometer & Nonius Kappa CCD \\
\hline Absorption correction & Multi-scan (Blessing, 1995) \\
\hline$T_{\min }, T_{\max }$ & $0.856,0.919$ \\
\hline $\begin{array}{l}\text { No. of measured, independent and } \\
\text { observed }[I>2 \sigma(I)] \text { reflections }\end{array}$ & $10879,2281,1835$ \\
\hline$R_{\text {int }}$ & 0.020 \\
\hline$(\sin \theta / \lambda)_{\max }\left(\AA^{-1}\right)$ & 0.602 \\
\hline \multicolumn{2}{|l|}{ Refinement } \\
\hline$R\left[F^{2}>2 \sigma\left(F^{2}\right)\right], w R\left(F^{2}\right), S$ & $0.052,0.113,0.96$ \\
\hline No. of reflections & 2281 \\
\hline No. of parameters & 172 \\
\hline H-atom treatment & H-atom parameters constrained \\
\hline$\Delta \rho_{\max }, \Delta \rho_{\min }\left(\mathrm{e} \AA^{-3}\right)$ & $0.17,-0.17$ \\
\hline
\end{tabular}

Computer programs: KappaCCD (Nonius, 1998), DENZO and SCALEPACK (Otwinowski \& Minor, 1997), SHELXS97 (Sheldrick, 2008), ORTEP-3 for Windows (Farrugia, 2012), Mercury (Macrae et al., 2020), SHELXL2014 (Sheldrick, 2015), PLATON (Spek, 2020) and publCIF (Westrip, 2010).

Technology (ATRST) and Abdelhamid Ibn Badis University of Mostaganem.

\section{References}

Alper, A. E. \& Taurins, A. (1967). Can. J. Chem. 45, 2903-2912.

Al-Rashood, K. A. \& Abdel-Aziz, H. A. (2010). Molecules, 15, 37753815.

Bahoussi, R. I., Djafri, A., Chouaih, A., Djafri, A. \& Hamzaoui, F. (2017). Acta Cryst. E73, 173-176.

Becke, A. D. (1993). J. Chem. Phys. 98, 5648-5652.

Belkafouf, N. E. H., Triki Baara, F., Altomare, A., Rizzi, R., Chouaih, A., Djafri, A. \& Hamzaoui, F. (2019). J. Mol. Struct. 1189, 8-20.

Bender, P. E., Hill, D., Offen, P. H., Razgaitis, K., Lavanchy, P., Stringer, O. D., Sutton, B. M., Griswold, D. E., DiMartino, M. \& Walz, D. T. (1985). J. Med. Chem. 28, 1169-1177.

Blessing, R. H. (1995). Acta Cryst. A51, 33-38.

Bodedla, G. B., Justin Thomas, K. R., Fan, M. S. \& Ho, K. C. (2016). J. Org. Chem. 81, 640-653.

Bruno, G., Chimirri, A., Monforte, A. M., Nicoló, F. \& Scopelliti, R. (1996). Acta Cryst. C52, 2531-2533.

Chimirri, A., Grasso, S., Monforte, P., Rao, A., Zappalà, M., Monforte, A. M., Pannecouque, C., Witvrouw, M., Balzarini, J. \& De Clercq, E. (1999). Antivir. Chem. Chemother. 10, 211-217.

Djafri, A., Chouaih, A., Daran, J.-C., Djafri, A. \& Hamzaoui, F. (2017). Acta Cryst. E73, 511-514.

El-Shorbagi, A., Hayallah, A. A., Omar, N. M. \& Ahmed, A. N. (2001). Bull. Pharm. Sci. Assiut, 24, 7-20.

Farrugia, L. J. (2012). J. Appl. Cryst. 45, 849-854.

Frisch, A., Nielson, A. B. \& Holder, A. J. (2000). GAUSSVIEW User Manual. Gaussian Inc, Pittsburgh.
Frisch, M. J., Trucks, G. W., Schlegel, H. B., Scuseria, G. E., Robb, M. A., Cheeseman, J. R., Scalmani, G., Barone, V., Mennucci, B., Petersson, G. A., Nakatsuji, H., Caricato, M., Li, X., Hratchian, H. P., Izmaylov, A. F., Bloino, J., Zheng, G., Sonnenberg, J. L., Hada, M., Ehara, M., Toyota, K., Fukuda, R., Hasegawa, J., Ishida, M., Nakajima, T., Honda, Y., Kitao, O., Nakai, H., Vreven, T., Montgomery, J. A. Jr, Peralta, J. E., Ogliaro, F., Bearpark, M., Heyd, J. J., Brothers, E., Kudin, K. N., Staroverov, V. N., Kobayashi, R., Normand, J., Raghavachari, K., Rendell, A., Burant, J. C., Iyengar, S. S., Tomasi, J., Cossi, M., Rega, N., Millam, J. M., Klene, M., Knox, J. E., Cross, J. B., Bakken, V., Adamo, C., Jaramillo, J., Gomperts, R., Stratmann, R. E., Yazyev, O., Austin, A. J., Cammi, R., Pomelli, C., Ochterski, J. W., Martin, R. L., Morokuma, K., Zakrzewski, V. G., Voth, G. A., Salvador, P., Dannenberg, J. J., Dapprich, S., Daniels, A. D., Farkas, Ö., Foresman, J. B., Ortiz, J. V., Cioslowski, J. \& Fox, D. J. (2009). GAUSSIAN09. Gaussian Inc., Wallingford, CT, USA.

Ghanavatkar, C. W., Mishra, V. R., Sekar, N., Mathew, E., Thomas, S. S. \& Joe, I. H. (2020). J. Mol. Struct. 1203, 127401.

Gong, S., Zhao, Y., Yang, C., Zhong, C., Qin, J. \& Ma, D. (2010). J. Phys. Chem. C114, 5193-5198.

Khelloul, N., Toubal, K., Benhalima, N., Rahmani, R., Chouaih, A., Djafri, A. \& Hamzaoui, F. (2016). Acta Chim. Slov. 63, 619-626.

Kourat, O., Djafri, A., Benhalima, N., Megrouss, Y., Belkafouf, N. E. H., Rahmani, R., Daran, J.-C., Djafri, A. \& Chouaih, A. (2020). J. Mol. Struct. 1222, 128952.

Krasovskii, A. N. \& Kochergin, P. M. (1972). Chem. Heterocycl. Compd. 5, 243-245.

Liang, Y., He, H.-W. \& Yang, Z.-W. (2009). Acta Cryst. E65, o3098.

Macrae, C. F., Sovago, I., Cottrell, S. J., Galek, P. T. A., McCabe, P., Pidcock, E., Platings, M., Shields, G. P., Stevens, J. S., Towler, M. \& Wood, P. A. (2020). J. Appl. Cryst. 53, 226-235.

Miller, L. F. \& Bambury, R. E. (1972). J. Med. Chem. 15, 415-417.

Nonius (1998). KappaCCD Reference Manual. Nonius BV, Delft, The Netherlands.

Ogura, H., Itoh, T. \& Tajika, T. (1968). J. Heterocycl. Chem. 5, 319322.

Oh, C., Ham, Y., Hong, S. \& Cho, J. (1995). Arch. Pharm. Pharm. Med. Chem. 328, 289-291.

Otwinowski, Z. \& Minor, W. (1997). Methods in Enzymology, Vol. 276, Macromolecular Crystallography, Part A, edited by C. W. Carter Jr \& R. M. Sweet, pp. 307-326. New York: Academic Press.

Park, Y. J., Such, K. H., Kang, E. C., Yoon, H. S., Kim, Y. H., Kang, D. P. \& Chang, M. S. (1993). Korean J. Med. Chem. 3, 124-129.

Rahmani, R., Djafri, A., Daran, J.-C., Djafri, A., Chouaih, A. \& Hamzaoui, F. (2016). Acta Cryst. E72, 155-157.

Roth, T., Morningstar, M. L., Boyer, P. L., Hughes, S. H., Buckheit, R. W. Jr \& Michejda, C. J. (1997). J. Med. Chem. 40, 4199-4207.

Sharpe, C. J., Shadbolt, R. S., Ashford, A. \& Ross, J. W. (1971). J. Med. Chem. 14, 977-982.

Sheldrick, G. M. (2008). Acta Cryst. A64, 112-122.

Sheldrick, G. M. (2015). Acta Cryst. C71, 3-8.

Singh, J. M. (1970). J. Med. Chem. 13, 1018.

Spek, A. L. (2020). Acta Cryst. E76, 1-11.

Turner, M. J., Mckinnon, J. J., Wolff, S. K., Grimwood, D. J., Spackman, P. R., Jayatilaka, D. \& Spackman, M. A. (2017). Crystal Explorer 17. The University of Western Australia.

Vijayan, N., Ramesh Babu, R., Gopalakrishnan, R., Ramasamy, P. \& Harrison, W. T. A. (2004). J. Cryst. Growth, 262, 490-498.

Wang, Z.-M., Yu, B., Cui, Y., Zhang, X.-Q. \& Sun, X.-Q. (2011). Acta Cryst. E67, o2540.

Westrip, S. P. (2010). J. Appl. Cryst. 43, 920-925.

Yahiaoui, S., Moliterni, A., Corriero, N., Cuocci, C., Toubal, K., Chouaih, A., Djafri, A. \& Hamzaoui, F. (2019). J. Mol. Struct. 1177, 186-192. 


\section{supporting information}

Acta Cryst. (2020). E76, 1832-1836 [https://doi.org/10.1107/S2056989020015017]

Molecular and crystal structure, Hirshfeld analysis and DFT investigation of 5-(furan-2-ylmethylidene)thiazolo[3,4-a]benzimidazole-2-thione

Hafsa Khaldi, Ahmed Djafri, Youcef Megrouss, Nawel Khelloul, Abdelkader Chouaih and Ayada Djafri

Computing details

Data collection: KappaCCD (Nonius, 1998); cell refinement: DENZO and SCALEPACK (Otwinowski \& Minor, 1997); data reduction: DENZO and SCALEPACK (Otwinowski \& Minor, 1997); program(s) used to solve structure: SHELXS97 (Sheldrick, 2008); program(s) used to refine structure: SHELXL2014 (Sheldrick, 2015); molecular graphics: ORTEP-3 for Windows (Farrugia, 2012), Mercury (Macrae et al., 2020); software used to prepare material for publication:

SHELXL2014 (Sheldrick, 2015), PLATON (Spek, 2020) and publCIF (Westrip, 2010).

5-(Furan-2-ylmethylidene)thiazolo[3,4-a]benzimidazole-2-thione

Crystal data

$\mathrm{C}_{14} \mathrm{H}_{8} \mathrm{~N}_{2} \mathrm{OS}_{2}$

$M_{r}=284.34$

Monoclinic, $P 2{ }_{1} / n$

$a=15.768(5) \AA$

$b=4.7583(15) \AA$

$c=17.316(6) \AA$

$\beta=101.572(8)^{\circ}$

$V=1272.8(7) \AA^{3}$

$Z=4$

Data collection

Nonius Kappa CCD diffractometer

Radiation source: sealed tube $\theta / 2 \theta$ scans

Absorption correction: multi-scan (Blessing, 1995)

$T_{\min }=0.856, T_{\max }=0.919$

10879 measured reflections

Refinement

Refinement on $F^{2}$

Least-squares matrix: full

$R\left[F^{2}>2 \sigma\left(F^{2}\right)\right]=0.052$

$w R\left(F^{2}\right)=0.113$

$S=0.96$

2281 reflections
$F(000)=584$

$D_{\mathrm{x}}=1.484 \mathrm{Mg} \mathrm{m}^{-3}$

Mo $K \alpha$ radiation, $\lambda=0.71073 \AA$

Cell parameters from 100 reflections

$\theta=2.0-25.3^{\circ}$

$\mu=0.41 \mathrm{~mm}^{-1}$

$T=295 \mathrm{~K}$

Prism, colourless

$0.58 \times 0.21 \times 0.20 \mathrm{~mm}$

2281 independent reflections 1835 reflections with $I>2 \sigma(I)$

$R_{\text {int }}=0.020$

$\theta_{\max }=25.4^{\circ}, \theta_{\min }=3.6^{\circ}$

$h=-18 \rightarrow 18$

$k=-5 \rightarrow 5$

$l=-20 \rightarrow 20$

172 parameters

0 restraints

Hydrogen site location: inferred from neighbouring sites

$\mathrm{H}$-atom parameters constrained 
$w=1 /\left[\sigma^{2}\left(F_{\mathrm{o}}^{2}\right)+(0.0089 P)^{2}+4.0499 P\right]$

where $P=\left(F_{\mathrm{o}}^{2}+2 F_{\mathrm{c}}^{2}\right) / 3$

$(\Delta / \sigma)_{\max }<0.001$

$$
\Delta \rho_{\max }=0.17 \text { e } \AA^{-3}
$$

\section{Special details}

Geometry. All esds (except the esd in the dihedral angle between two 1.s. planes) are estimated using the full covariance matrix. The cell esds are taken into account individually in the estimation of esds in distances, angles and torsion angles; correlations between esds in cell parameters are only used when they are defined by crystal symmetry. An approximate (isotropic) treatment of cell esds is used for estimating esds involving l.s. planes.

Fractional atomic coordinates and isotropic or equivalent isotropic displacement parameters $\left(\AA^{2}\right)$

\begin{tabular}{lllll}
\hline & $x$ & $y$ & $z$ & $U_{\text {iso }} * U_{\text {eq }}$ \\
\hline S1 & $0.01611(6)$ & $0.1179(2)$ & $0.89016(5)$ & $0.0504(3)$ \\
S2 & $-0.14717(8)$ & $-0.2152(3)$ & $0.85975(7)$ & $0.0732(4)$ \\
O1 & $0.15244(16)$ & $0.5043(6)$ & $0.94349(14)$ & $0.0523(7)$ \\
C14 & $0.0218(2)$ & $-0.4142(8)$ & $0.67488(18)$ & $0.0432(9)$ \\
N1 & $-0.01982(18)$ & $-0.2326(7)$ & $0.77765(15)$ & $0.0436(7)$ \\
C9 & $-0.0453(2)$ & $-0.4245(9)$ & $0.71658(19)$ & $0.0467(9)$ \\
C7 & $0.0587(2)$ & $-0.1218(8)$ & $0.76838(19)$ & $0.0427(9)$ \\
C11 & $-0.1192(3)$ & $-0.7634(9)$ & $0.6302(2)$ & $0.0536(10)$ \\
H11 & -0.1661 & -0.8825 & 0.6139 & $0.064^{*}$ \\
N2 & $0.08686(18)$ & $-0.2264(7)$ & $0.70874(15)$ & $0.0430(7)$ \\
C8 & $-0.0552(2)$ & $-0.1294(9)$ & $0.83946(19)$ & $0.0467(9)$ \\
C13 & $0.0170(2)$ & $-0.5792(9)$ & $0.60819(19)$ & $0.0485(10)$ \\
H13 & 0.0595 & -0.5718 & 0.5780 & $0.058^{*}$ \\
C6 & $0.0923(2)$ & $0.0822(8)$ & $0.82795(19)$ & $0.0430(9)$ \\
C5 & $0.1667(2)$ & $0.2165(8)$ & $0.8349(2)$ & $0.0433(9)$ \\
H5 & 0.1996 & 0.1713 & 0.7976 & $0.052^{*}$ \\
C3 & $0.2789(2)$ & $0.5589(8)$ & $0.9074(2)$ & $0.0490(9)$ \\
H3 & 0.3240 & 0.5411 & 0.8804 & $0.059^{*}$ \\
C10 & $-0.1160(2)$ & $-0.5960(9)$ & $0.6964(2)$ & $0.0503(10)$ \\
H10 & -0.1595 & -0.6002 & 0.7255 & $0.060^{*}$ \\
C4 & $0.2034(2)$ & $0.4222(8)$ & $0.8920(2)$ & $0.0462(9)$ \\
C1 & $0.2005(3)$ & $0.6951(9)$ & $0.9914(2)$ & $0.0551(10)$ \\
H1 & 0.1822 & 0.7867 & 1.0326 & $0.066^{*}$ \\
C2 & $0.2770(3)$ & $0.7349(9)$ & $0.9723(2)$ & $0.0540(10)$ \\
H2 & 0.3206 & 0.8552 & 0.9969 & $0.065^{*}$ \\
C12 & $-0.0534(3)$ & $-0.7544(9)$ & $0.5885(2)$ & $0.0574(11)$ \\
H12 & -0.0568 & -0.8722 & 0.5452 & $0.069^{*}$ \\
& & & &
\end{tabular}

Atomic displacement parameters $\left(\AA^{2}\right)$

\begin{tabular}{lllllll}
\hline & $U^{11}$ & $U^{22}$ & $U^{33}$ & $U^{12}$ & $U^{13}$ & $U^{23}$ \\
\hline S1 & $0.0569(6)$ & $0.0590(6)$ & $0.0373(5)$ & $-0.0007(5)$ & $0.0142(4)$ & $-0.0071(5)$ \\
S2 & $0.0644(7)$ & $0.0958(10)$ & $0.0690(7)$ & $-0.0167(7)$ & $0.0360(6)$ & $-0.0209(7)$ \\
O1 & $0.0584(16)$ & $0.0575(17)$ & $0.0423(14)$ & $-0.0015(14)$ & $0.0132(12)$ & $-0.0078(13)$ \\
C14 & $0.053(2)$ & $0.047(2)$ & $0.0274(16)$ & $0.0062(19)$ & $0.0031(15)$ & $0.0015(17)$ \\
N1 & $0.0464(17)$ & $0.0520(19)$ & $0.0331(15)$ & $0.0008(15)$ & $0.0099(13)$ & $0.0005(14)$
\end{tabular}


supporting information

\begin{tabular}{lllllll} 
C9 & $0.052(2)$ & $0.052(2)$ & $0.0342(18)$ & $0.0062(19)$ & $0.0032(16)$ & $0.0032(18)$ \\
C7 & $0.048(2)$ & $0.050(2)$ & $0.0316(17)$ & $0.0049(18)$ & $0.0099(15)$ & $0.0058(17)$ \\
C11 & $0.058(2)$ & $0.058(3)$ & $0.040(2)$ & $0.000(2)$ & $-0.0011(17)$ & $-0.003(2)$ \\
N2 & $0.0497(17)$ & $0.0521(19)$ & $0.0271(14)$ & $0.0028(15)$ & $0.0079(13)$ & $0.0038(14)$ \\
C8 & $0.052(2)$ & $0.056(2)$ & $0.0347(18)$ & $0.0025(19)$ & $0.0132(16)$ & $-0.0015(18)$ \\
C13 & $0.060(2)$ & $0.056(3)$ & $0.0300(17)$ & $0.009(2)$ & $0.0082(16)$ & $0.0036(18)$ \\
C6 & $0.049(2)$ & $0.049(2)$ & $0.0316(17)$ & $0.0033(19)$ & $0.0103(15)$ & $-0.0033(17)$ \\
C5 & $0.054(2)$ & $0.040(2)$ & $0.0389(18)$ & $0.0017(18)$ & $0.0157(16)$ & $0.0063(17)$ \\
C3 & $0.055(2)$ & $0.053(3)$ & $0.0399(19)$ & $-0.003(2)$ & $0.0102(17)$ & $-0.0020(18)$ \\
C10 & $0.057(2)$ & $0.058(3)$ & $0.0334(18)$ & $0.004(2)$ & $0.0020(16)$ & $0.0011(19)$ \\
C4 & $0.055(2)$ & $0.046(2)$ & $0.0377(19)$ & $0.0021(19)$ & $0.0106(16)$ & $0.0023(18)$ \\
C1 & $0.069(3)$ & $0.055(3)$ & $0.041(2)$ & $0.003(2)$ & $0.0097(19)$ & $-0.010(2)$ \\
C2 & $0.061(2)$ & $0.057(3)$ & $0.041(2)$ & $-0.006(2)$ & $0.0041(18)$ & $-0.006(2)$ \\
C12 & $0.072(3)$ & $0.059(3)$ & $0.037(2)$ & $0.013(2)$ & $-0.0003(19)$ & $-0.008(2)$ \\
& & & & & & \\
\hline
\end{tabular}

Geometric parameters $\left(A,{ }^{\circ}\right)$

\begin{tabular}{|c|c|c|c|}
\hline $\mathrm{S} 1-\mathrm{C} 8$ & $1.739(4)$ & $\mathrm{C} 11-\mathrm{C} 10$ & $1.388(5)$ \\
\hline $\mathrm{S} 1-\mathrm{C} 6$ & $1.775(3)$ & C11-H11 & 0.9300 \\
\hline $\mathrm{S} 2-\mathrm{C} 8$ & $1.612(4)$ & $\mathrm{C} 13-\mathrm{C} 12$ & $1.376(6)$ \\
\hline $\mathrm{O} 1-\mathrm{C} 1$ & $1.354(5)$ & $\mathrm{C} 13-\mathrm{H} 13$ & 0.9300 \\
\hline $\mathrm{O} 1-\mathrm{C} 4$ & $1.372(4)$ & $\mathrm{C} 6-\mathrm{C} 5$ & $1.320(5)$ \\
\hline $\mathrm{C} 14-\mathrm{C} 13$ & $1.386(5)$ & $\mathrm{C} 5-\mathrm{C} 4$ & $1.429(5)$ \\
\hline $\mathrm{C} 14-\mathrm{C} 9$ & $1.397(5)$ & $\mathrm{C} 5-\mathrm{H} 5$ & 0.9300 \\
\hline $\mathrm{C} 14-\mathrm{N} 2$ & $1.397(5)$ & $\mathrm{C} 3-\mathrm{C} 4$ & $1.336(5)$ \\
\hline $\mathrm{N} 1-\mathrm{C} 7$ & $1.384(4)$ & $\mathrm{C} 3-\mathrm{C} 2$ & $1.407(5)$ \\
\hline $\mathrm{N} 1-\mathrm{C} 8$ & $1.392(4)$ & $\mathrm{C} 3-\mathrm{H} 3$ & 0.9300 \\
\hline $\mathrm{N} 1-\mathrm{C} 9$ & $1.394(5)$ & $\mathrm{C} 10-\mathrm{H} 10$ & 0.9300 \\
\hline $\mathrm{C} 9-\mathrm{C} 10$ & $1.368(5)$ & $\mathrm{C} 1-\mathrm{C} 2$ & $1.326(5)$ \\
\hline $\mathrm{C} 7-\mathrm{N} 2$ & $1.302(4)$ & $\mathrm{C} 1-\mathrm{H} 1$ & 0.9300 \\
\hline $\mathrm{C} 7-\mathrm{C} 6$ & $1.438(5)$ & $\mathrm{C} 2-\mathrm{H} 2$ & 0.9300 \\
\hline $\mathrm{C} 11-\mathrm{C} 12$ & $1.378(5)$ & $\mathrm{C} 12-\mathrm{H} 12$ & 0.9300 \\
\hline $\mathrm{C} 8-\mathrm{S} 1-\mathrm{C} 6$ & 94.40 (17) & $\mathrm{C} 5-\mathrm{C} 6-\mathrm{C} 7$ & $125.8(3)$ \\
\hline $\mathrm{C} 1-\mathrm{O} 1-\mathrm{C} 4$ & $105.1(3)$ & $\mathrm{C} 5-\mathrm{C} 6-\mathrm{S} 1$ & $126.6(3)$ \\
\hline $\mathrm{C} 13-\mathrm{C} 14-\mathrm{C} 9$ & $119.3(4)$ & $\mathrm{C} 7-\mathrm{C} 6-\mathrm{S} 1$ & $107.6(3)$ \\
\hline $\mathrm{C} 13-\mathrm{C} 14-\mathrm{N} 2$ & $128.7(3)$ & $\mathrm{C} 6-\mathrm{C} 5-\mathrm{C} 4$ & $128.6(3)$ \\
\hline $\mathrm{C} 9-\mathrm{C} 14-\mathrm{N} 2$ & $112.0(3)$ & $\mathrm{C} 6-\mathrm{C} 5-\mathrm{H} 5$ & 115.7 \\
\hline $\mathrm{C} 7-\mathrm{N} 1-\mathrm{C} 8$ & $117.4(3)$ & $\mathrm{C} 4-\mathrm{C} 5-\mathrm{H} 5$ & 115.7 \\
\hline $\mathrm{C} 7-\mathrm{N} 1-\mathrm{C} 9$ & $106.9(3)$ & $\mathrm{C} 4-\mathrm{C} 3-\mathrm{C} 2$ & $106.7(3)$ \\
\hline $\mathrm{C} 8-\mathrm{N} 1-\mathrm{C} 9$ & $135.7(3)$ & $\mathrm{C} 4-\mathrm{C} 3-\mathrm{H} 3$ & 126.6 \\
\hline $\mathrm{C} 10-\mathrm{C} 9-\mathrm{N} 1$ & $132.9(3)$ & $\mathrm{C} 2-\mathrm{C} 3-\mathrm{H} 3$ & 126.6 \\
\hline $\mathrm{C} 10-\mathrm{C} 9-\mathrm{C} 14$ & $123.5(3)$ & $\mathrm{C} 9-\mathrm{C} 10-\mathrm{C} 11$ & $116.5(4)$ \\
\hline $\mathrm{N} 1-\mathrm{C} 9-\mathrm{C} 14$ & $103.6(3)$ & $\mathrm{C} 9-\mathrm{C} 10-\mathrm{H} 10$ & 121.8 \\
\hline $\mathrm{N} 2-\mathrm{C} 7-\mathrm{N} 1$ & $113.7(3)$ & $\mathrm{C} 11-\mathrm{C} 10-\mathrm{H} 10$ & 121.8 \\
\hline $\mathrm{N} 2-\mathrm{C} 7-\mathrm{C} 6$ & $133.7(3)$ & $\mathrm{C} 3-\mathrm{C} 4-\mathrm{O} 1$ & $110.3(3)$ \\
\hline $\mathrm{N} 1-\mathrm{C} 7-\mathrm{C} 6$ & $112.6(3)$ & $\mathrm{C} 3-\mathrm{C} 4-\mathrm{C} 5$ & $133.8(3)$ \\
\hline $\mathrm{C} 12-\mathrm{C} 11-\mathrm{C} 10$ & $120.5(4)$ & $\mathrm{O} 1-\mathrm{C} 4-\mathrm{C} 5$ & $115.9(3)$ \\
\hline
\end{tabular}




\begin{tabular}{|c|c|c|c|}
\hline $\mathrm{C} 12-\mathrm{C} 11-\mathrm{H} 11$ & 119.7 & $\mathrm{C} 2-\mathrm{C} 1-\mathrm{O} 1$ & $111.6(3)$ \\
\hline $\mathrm{C} 10-\mathrm{C} 11-\mathrm{H} 11$ & 119.7 & $\mathrm{C} 2-\mathrm{C} 1-\mathrm{H} 1$ & 124.2 \\
\hline $\mathrm{C} 7-\mathrm{N} 2-\mathrm{C} 14$ & $103.8(3)$ & $\mathrm{O} 1-\mathrm{C} 1-\mathrm{H} 1$ & 124.2 \\
\hline $\mathrm{N} 1-\mathrm{C} 8-\mathrm{S} 2$ & $126.5(3)$ & $\mathrm{C} 1-\mathrm{C} 2-\mathrm{C} 3$ & $106.3(4)$ \\
\hline $\mathrm{N} 1-\mathrm{C} 8-\mathrm{S} 1$ & $108.0(3)$ & $\mathrm{C} 1-\mathrm{C} 2-\mathrm{H} 2$ & 126.8 \\
\hline $\mathrm{S} 2-\mathrm{C} 8-\mathrm{S} 1$ & $125.5(2)$ & $\mathrm{C} 3-\mathrm{C} 2-\mathrm{H} 2$ & 126.8 \\
\hline $\mathrm{C} 12-\mathrm{C} 13-\mathrm{C} 14$ & $117.1(4)$ & $\mathrm{C} 13-\mathrm{C} 12-\mathrm{C} 11$ & $123.0(4)$ \\
\hline $\mathrm{C} 12-\mathrm{C} 13-\mathrm{H} 13$ & 121.4 & $\mathrm{C} 13-\mathrm{C} 12-\mathrm{H} 12$ & 118.5 \\
\hline $\mathrm{C} 14-\mathrm{C} 13-\mathrm{H} 13$ & 121.4 & $\mathrm{C} 11-\mathrm{C} 12-\mathrm{H} 12$ & 118.5 \\
\hline $\mathrm{C} 7-\mathrm{N} 1-\mathrm{C} 9-\mathrm{C} 10$ & $179.5(4)$ & $\mathrm{N} 2-\mathrm{C} 14-\mathrm{C} 13-\mathrm{C} 12$ & $178.0(4)$ \\
\hline $\mathrm{C} 8-\mathrm{N} 1-\mathrm{C} 9-\mathrm{C} 10$ & $-3.1(7)$ & $\mathrm{N} 2-\mathrm{C} 7-\mathrm{C} 6-\mathrm{C} 5$ & $-0.5(7)$ \\
\hline $\mathrm{C} 7-\mathrm{N} 1-\mathrm{C} 9-\mathrm{C} 14$ & $0.3(4)$ & $\mathrm{N} 1-\mathrm{C} 7-\mathrm{C} 6-\mathrm{C} 5$ & $178.3(4)$ \\
\hline $\mathrm{C} 8-\mathrm{N} 1-\mathrm{C} 9-\mathrm{C} 14$ & $177.7(4)$ & $\mathrm{N} 2-\mathrm{C} 7-\mathrm{C} 6-\mathrm{S} 1$ & $179.8(4)$ \\
\hline $\mathrm{C} 13-\mathrm{C} 14-\mathrm{C} 9-\mathrm{C} 10$ & $1.7(6)$ & $\mathrm{N} 1-\mathrm{C} 7-\mathrm{C} 6-\mathrm{S} 1$ & $-1.4(4)$ \\
\hline $\mathrm{N} 2-\mathrm{C} 14-\mathrm{C} 9-\mathrm{C} 10$ & $-178.7(3)$ & $\mathrm{C} 8-\mathrm{S} 1-\mathrm{C} 6-\mathrm{C} 5$ & $-179.0(4)$ \\
\hline $\mathrm{C} 13-\mathrm{C} 14-\mathrm{C} 9-\mathrm{N} 1$ & $-179.0(3)$ & $\mathrm{C} 8-\mathrm{S} 1-\mathrm{C} 6-\mathrm{C} 7$ & $0.7(3)$ \\
\hline $\mathrm{N} 2-\mathrm{C} 14-\mathrm{C} 9-\mathrm{N} 1$ & $0.6(4)$ & $\mathrm{C} 7-\mathrm{C} 6-\mathrm{C} 5-\mathrm{C} 4$ & $179.5(4)$ \\
\hline $\mathrm{C} 8-\mathrm{N} 1-\mathrm{C} 7-\mathrm{N} 2$ & $-179.2(3)$ & $\mathrm{S} 1-\mathrm{C} 6-\mathrm{C} 5-\mathrm{C} 4$ & $-0.9(6)$ \\
\hline $\mathrm{C} 9-\mathrm{N} 1-\mathrm{C} 7-\mathrm{N} 2$ & $-1.2(4)$ & $\mathrm{N} 1-\mathrm{C} 9-\mathrm{C} 10-\mathrm{C} 11$ & $-179.7(4)$ \\
\hline $\mathrm{C} 8-\mathrm{N} 1-\mathrm{C} 7-\mathrm{C} 6$ & $1.8(5)$ & $\mathrm{C} 14-\mathrm{C} 9-\mathrm{C} 10-\mathrm{C} 11$ & $-0.7(6)$ \\
\hline $\mathrm{C} 9-\mathrm{N} 1-\mathrm{C} 7-\mathrm{C} 6$ & $179.7(3)$ & $\mathrm{C} 12-\mathrm{C} 11-\mathrm{C} 10-\mathrm{C} 9$ & $0.5(6)$ \\
\hline $\mathrm{N} 1-\mathrm{C} 7-\mathrm{N} 2-\mathrm{C} 14$ & $1.5(4)$ & $\mathrm{C} 2-\mathrm{C} 3-\mathrm{C} 4-\mathrm{O} 1$ & $0.7(4)$ \\
\hline $\mathrm{C} 6-\mathrm{C} 7-\mathrm{N} 2-\mathrm{C} 14$ & $-179.7(4)$ & $\mathrm{C} 2-\mathrm{C} 3-\mathrm{C} 4-\mathrm{C} 5$ & $-179.5(4)$ \\
\hline $\mathrm{C} 13-\mathrm{C} 14-\mathrm{N} 2-\mathrm{C} 7$ & $178.2(4)$ & $\mathrm{C} 1-\mathrm{O} 1-\mathrm{C} 4-\mathrm{C} 3$ & $-0.6(4)$ \\
\hline $\mathrm{C} 9-\mathrm{C} 14-\mathrm{N} 2-\mathrm{C} 7$ & $-1.3(4)$ & $\mathrm{C} 1-\mathrm{O} 1-\mathrm{C} 4-\mathrm{C} 5$ & $179.5(3)$ \\
\hline $\mathrm{C} 7-\mathrm{N} 1-\mathrm{C} 8-\mathrm{S} 2$ & $177.2(3)$ & $\mathrm{C} 6-\mathrm{C} 5-\mathrm{C} 4-\mathrm{C} 3$ & $175.6(4)$ \\
\hline $\mathrm{C} 9-\mathrm{N} 1-\mathrm{C} 8-\mathrm{S} 2$ & $0.0(6)$ & $\mathrm{C} 6-\mathrm{C} 5-\mathrm{C} 4-\mathrm{O} 1$ & $-4.5(6)$ \\
\hline $\mathrm{C} 7-\mathrm{N} 1-\mathrm{C} 8-\mathrm{S} 1$ & $-1.2(4)$ & $\mathrm{C} 4-\mathrm{O} 1-\mathrm{C} 1-\mathrm{C} 2$ & $0.2(4)$ \\
\hline $\mathrm{C} 9-\mathrm{N} 1-\mathrm{C} 8-\mathrm{S} 1$ & $-178.4(3)$ & $\mathrm{O} 1-\mathrm{C} 1-\mathrm{C} 2-\mathrm{C} 3$ & $0.2(5)$ \\
\hline $\mathrm{C} 6-\mathrm{S} 1-\mathrm{C} 8-\mathrm{N} 1$ & $0.3(3)$ & $\mathrm{C} 4-\mathrm{C} 3-\mathrm{C} 2-\mathrm{C} 1$ & $-0.5(5)$ \\
\hline $\mathrm{C} 6-\mathrm{S} 1-\mathrm{C} 8-\mathrm{S} 2$ & $-178.1(3)$ & $\mathrm{C} 14-\mathrm{C} 13-\mathrm{C} 12-\mathrm{C} 11$ & $2.4(6)$ \\
\hline $\mathrm{C} 9-\mathrm{C} 14-\mathrm{C} 13-\mathrm{C} 12$ & $-2.5(5)$ & $\mathrm{C} 10-\mathrm{C} 11-\mathrm{C} 12-\mathrm{C} 13$ & $-1.4(6)$ \\
\hline
\end{tabular}

Hydrogen-bond geometry $\left(A,{ }^{\circ}\right)$

\begin{tabular}{lllll}
\hline$D-\mathrm{H} \cdots A$ & $D-\mathrm{H}$ & $\mathrm{H} \cdots A$ & $D \cdots A$ & $D-\mathrm{H} \cdots A$ \\
\hline $\mathrm{C} 10-\mathrm{H} 10 \cdots \mathrm{S} 2$ & 0.93 & 2.94 & $3.476(4)$ & 119 \\
$\mathrm{C} 3-\mathrm{H} 3 \cdots \mathrm{N} 2 \mathrm{i}$ & 0.93 & 2.62 & $3.474(5)$ & 154 \\
$\mathrm{C} 1-\mathrm{H} 1 \cdots \mathrm{S} 2^{\mathrm{ii}}$ & 0.93 & 2.89 & $3.788(4)$ & 163
\end{tabular}

Symmetry codes: (i) $-x+1 / 2, y+1 / 2,-z+3 / 2$; (ii) $-x,-y+1,-z+2$. 